Acta Regionalia et Environmentalica 2

Nitra, Slovaca Universitas Agriculturae Nitriae, 2018, pp. 51-56

\title{
THIRD SECTOR INSTITUTIONS AT THE LOCAL LEVEL AND THEIR IMPACT ON HUMAN DEVELOPMENT
}

\author{
Lukáš VARECHA \\ Slovak University of Agriculture in Nitra, Slovak Republic
}

\begin{abstract}
In the paper, we analyse the relationship between third sector local institutions, which represent a component of social capital, and human development at the level of Slovak municipalities. In order to measure human development we use modified human development index, reflecting unemployment, level of education and gross mortality rate. We hypothesize that third sector institutions acting at the local level have a positive impact on human development. We utilize regression analysis in order to reveal this relationship, using cross-sectional data. Statistical results confirm our hypothesis. There is a positive and statistically significant relationship between the number of civic associations and the level of the human development index, even when filtering out other impacts, including self-government organizations per 1,000 inhabitants and net assets of the municipality per inhabitant. This result may be explained by the concept of social capital, meaning the network of interest-group relationships has a positive impact on providing services, governance and better access to less accessible forms of capital.
\end{abstract}

Keywords: local institutions, voluntary associations, social capital, human development

Institutions play an important role in ensuring the competitiveness of regions and their ability to face the challenges of contemporary world. Douglass C. North (1990) defined institutions as humanly created constraints creating a structure in human interaction. They represent the rules according to which the interaction between actors functions, and they are also organizations that implement these rules to achieve their goals (World Bank, 2002). Institutions are not a part of natural resources, neither they are physical objects created by human beings. They are a feature of the human population of a given society (Davis, 2010).

Many institutions operate at a national level. However, local institutions are much more important in improving the performance of local and regional economies (Martin and Sunley, 2003). Local institutions are important because they can eliminate uncertainty and instability. They can strengthen participation, resolve conflicts and secure connections with external actors (Uphoff and Buck, 2006). Local social institutions provide services essential to meeting the physical, social and cultural needs of the community (Flora et al., 1992). In the context of sustainable rural development, the importance of local institutions is increasing. High et al. (2005) believe that to understand the organizations and institutions which create them also means to understand a significant part of rural development.

Formal institutions at the level of smaller territorial units include local and regional self-government, legislation and conventions. However, informal relationships and bonds among actors are considered the most important
(Clingermayer and Feiock, 2001). Informal institutions include standards, traditions, social conventions, interpersonal contacts, relationships and informal networks (Roriguez-Pose and Storper, 2006). A significant comparative advantage of rural areas is the high density of informal institutions. In general, one of the features of rural areas is the reciprocity and solidarity of the rural population, local habits and traditions (Binek et al., 2009).

The cause of the importance of relationships and contacts of social groups and networks, trust in community members is explained by the concept of social capital (Fukuyama, 1995). Social capital is a resource that can be utilised even by communities with limited access to other resources - to human, physical or financial capital (Woolcock, 2002). It is the local level that is significant in the context of social capital. This is where shared norms and shared values prevail, and there is the highest number of interactions among economic actors. The rich network of relationships between interest groups and local public institutions then positively influences infrastructure building and service provision, investment and better governance. It plays an important role in local development (Jēkabsone and Sloka, 2016). The importance of informal relations in the context of rural development in Slovak conditions was confirmed by Melichová (2015).

However, it is not optimal for relations among actors to be based only on mutual trust. As Fukuyama (1995) asserts, there is a complementary relationship between social capital and formal institutions - formal institutions need to be established. Without them a community with 
a high supply of trust and community spirit faces barriers to their further development. Conversely, if formal institutions are established, they are essentially useless if individuals exploit them in order to achieve personal goals.

For individuals, voluntary associations are often the most common way to get involved in community life (Binek et al., 2007). Membership in them is more common in rural areas, and it is also common to have membership in more than one voluntary association (Svobodová et al., 2011). The importance of civic engagement in the form of voluntary associations is underlined by Putnam $(1993,2000)$. He claims that differences in regional development are explained by differences in the stock of social capital that is represented by civil society, institutional performance and local self-government. Voluntary cooperation is therefore easier in a community where reciprocal relationships and networks of civic engagement are created. The effective use of social capital is then an important task for the community.

Many studies have dealt with the impact of social capital on economy, namely on economic growth, unemployment, corruption or government performance. Most studies looked at the effects of social capital at state or regional level but only a few addressed this issue at the local level (Cofee and Geys, 2005). Economic development should ultimately be reflected in human development and in ensuring a higher quality of life for the affected community. Human development does not only mean an increase in income but also a satisfaction of needs such as health care or education. These are provided not only by the public sector but also by social and political institutions (Flora et al., 1992; Christoforou, 2010).

\section{Material and methods}

The aim of the paper is to examine the impact of local institutions on human development in Slovak municipalities. Particularly, we examine the relationship between human development and civic associations as a component of social capital. In order to investigate the relationship, we compile a regression model consisting of cross-sectional data for 2015. We used the data from the Statistical Office of the Slovak Republic, 2011 Population and Housing Census, Register of economic organisations of SR, and the database on municipality economies of INEKO. We hypothesize there is a positive relationship between social capital, expressed by its component - civic associations, and the modified human development index.

The modified human development index, constructed in a similar fashion as the index constructed by Humlerová (2013), serves as a dependent variable. This indicator is comprised of three dimensions: level of education, life expectancy and economic conditions. In its original form, it is used to measure human development at national level (UNDP, 2016). At municipal level, data for its calculation is not available. Therefore, it is replaced with alternative indicators. We use 2011 weighted education index (1) to reflect the level of education. It is based on the number of years of study and from among the partial indicators it resembles the original indicator to the greatest extent:

$$
\text { weighted education index }=\frac{\sum_{i=1}^{12} w_{i} \text { population }}{\text { adult population }}
$$

where:

$w_{i} \quad=($ number of completed years of study $i) / 9$ for $i=1,2, \ldots 12$

Life Expectancy is replaced by gross mortality rate and the dimension of economic conditions (Income Index) is represented by unemployment. Since there is no data on the economically active population at municipal level, it is represented as the available number of job seekers divided by the number of the productive population. Since indicators representing individual dimensions of human development are measured in different units, it is necessary to standardize them. Standardization is performed using the max - min method (2), which guarantees values in the $<0,1>$ interval:

$$
z_{i}=\frac{x_{i}-\min (x)}{\max (x)-\min (x)}
$$

where:

$x_{i}=\left(x_{1} \ldots, x_{n}\right)$ and zi represents standardized values

Unlike the other two sub-indicators, higher values of weighted education index are positive phenomenon. Therefore, we use inverted value of this indicator, more precisely its standardized value substracted from one. In the next step, the index itself (3) is calculated as the mean of the standardized values of individual indicators. Considering the rather cumbersome interpretation, resulting index is then inverted again. Therefore, the increasing value of these indicators indicates a higher level of human development:

$$
H D I_{i}=1-\left(\frac{\text { life expectancy index }+(1-\text { education index })+\text { income index }}{3}\right)
$$

where:

$\mathrm{HDI}_{i}$ - represents human development index of the municipality $i$

Activities of civic associations can be measured by their number, total number of their members per capita or the frequency of its member's meetings (Rupasingha et al., 2002). In our case the density of civic associations amounts to a total number of civic associations per 1,000 inhabitants in 2015.

In order to uncover the relationship between local institutions and human development, it is necessary to filter out the possible impact of other determinants. In our models, we include a series of control variables. We also control the impact of public administration institutions, represented by budgetary and 
Table 1 Overview of variables and their descriptive statistics

\begin{tabular}{|c|c|c|c|c|c|c|c|}
\hline Variable & Description & Mean & Median & S. D. & Min & Max & Source \\
\hline DENSITY & population density & 110.54 & 58.82 & 382.13 & 1.3 & 13,692 & Datacube, 2015 \\
\hline MP & the mid-year population & $1,856.9$ & 665.5 & 5,828 & 11 & 104,165 & Datacube, 2015 \\
\hline CP & crude rate of population change & 0.0591 & 0.000 & 23.4 & -353 & 277 & Datacube, 2015 \\
\hline AMW & $\begin{array}{l}\text { district average gross nominal monthly } \\
\text { wage by labour force sample survey }\end{array}$ & 828 & 812 & 106 & 636 & 1,446 & Datacube, 2015 \\
\hline UNEMP & district registered unemployment rate & 13.1 & 12.2 & 5.58 & 4.67 & 27.4 & Datacube, 2015 \\
\hline BUILT & built-up area share & 0.0519 & 0.0431 & 0.0473 & 0.00364 & 0.801 & Datacube, 2015 \\
\hline HF & health facilities per 1,000 inhabitants & 0.645 & 0.000 & 1.75 & 0.000 & 40.8 & Datacube, 2015 \\
\hline VA & $\begin{array}{l}\text { voluntary associations per 1,000 } \\
\text { inhabitants }\end{array}$ & 7.14 & 5.91 & 6.33 & 0.000 & 97.6 & $\begin{array}{l}\text { Register of economic } \\
\text { organisations of SR }\end{array}$ \\
\hline MORG & $\begin{array}{l}\text { budgetary, contributory and other } \\
\text { organisations owned by municipality } \\
\text { per } 1,000 \text { inhabitants }\end{array}$ & 0.575 & 0.000 & 1.08 & 0.000 & 24.1 & $\begin{array}{l}\text { Register of economic } \\
\text { organisations of SR }\end{array}$ \\
\hline ASSETS & net assets per inhabitant & 2010.9 & 1616.4 & 1838.7 & $-6,967.3$ & 42,055 & INEKO, 2015 \\
\hline PREPR & pre-productive age group share & 15.4 & 14.6 & 5.18 & 1.69 & 45.5 & Datacube, 2015 \\
\hline POSTPR & post-productive age group share & 15.5 & 15.0 & 4.79 & 1.20 & 55.8 & Datacube, 2015 \\
\hline HDI & constructed human development index & 0.681 & 0.696 & 0.0691 & 0.307 & 0.852 & $\begin{array}{l}\text { Datacube, 2015; } \\
\text { SODB } 2011\end{array}$ \\
\hline
\end{tabular}

Source: own processing

contributory organizations, as well as by various other less common organizations owned by municipality per 1,000 inhabitants. In addition to the number of organizations, we use net municipal assets per inhabitants, assuming higher net assets per capita increase the ability of self-government to meet the needs of its inhabitants. Table 1 shows descriptive statistic of used variables. After adding control variables, the regression model has the following form:

$$
\begin{gathered}
\text { HDI }_{i}=\beta_{0}+\beta_{1} \ln \left(\text { DENSITY }_{i}\right)+\beta_{2} \ln \left(\mathrm{MP}_{i}+\beta_{3} \mathrm{CP}_{i}+\beta_{4} \mathrm{AMW}_{i}+\right. \\
+\beta \mathrm{UNEMP}_{i}+\beta_{6} \mathrm{BUILT}_{i}+\beta \mathrm{BHF}_{i}+\beta 8 \mathrm{PREPR}_{i}+\beta_{9} \mathrm{POSTPR}_{i}+ \\
+\beta_{10} \mathrm{MORG}_{i}+\beta_{11} \mathrm{ASSETS}_{i}+\beta_{12} \mathrm{VA}_{i}+\varepsilon_{i}
\end{gathered}
$$

where:

$i=1,2 \ldots 2,861$ represents municipalities in Slovakia

\section{Results and discussion}

Table 2 shows regression models estimated using the OLS method. Since heteroskedasticity has been detected, we use robust standard errors estimate. Regarding the presence of multi-collinearity of independent variables, low VIF values indicate that the results are not affected by multi-collinearity (Hair et al., 2014).

In the first model (1), we do not take the effects of voluntary associations into account. Variables in the model explain approximately $57 \%$ of the variability of the modified human development index and the overall model is statistically significant. Most coefficients of control variables are statistically significant. There is, therefore, a statistically significant relationship of the human development index, for example, with the district registered unemployment rate, district average gross nominal monthly wage or crude rate of population change. As we expected, population density affects the level of human development index positively. With rising density, various commercial, educational and other facilities will be localised in these municipalities providing their inhabitants with sophisticated goods and services. This is evident also from the positive relation of dependent variable with the number of health facilities. The size of the municipality, represented by the number of inhabitants does not have a statistically significant impact on the human development index. With regard to public administration institutions, in the case of the number of organizations themselves, the relationship between the variables is negative but not statistically significant. We explain this by the nature of the organizations making up this variable - a substantial part (80\%) consists of budget and contributory organizations, namely school facilities. In the context of social capital, some authors (Kubišová, 2016; Svobodová et al., 2011; Kadeřábková and Trhlínová, 2006) attribute some importance to school facilities. They point out that school facilities provide a place for people to meet in a village. They are involved in the development of social and cultural life through the preparation and implementation of various activities. If there is no space in the municipality for the organization of social and cultural events, the social life of the population is diminishing and so is their cohesion. There is a positive relationship between the human development index and the value of net assets per capita. Municipal amenities may be to a certain extent represented by the net municipal assets per capita.

In the second model (2), we include the number of voluntary organisations representing local institutions. We test the hypothesis whether local institutions affect human development. We observe a minor increase in 
Table 2 Regression analysis results

\begin{tabular}{|c|c|c|c|c|}
\hline Dependent variable: HDI & (1) & VIF & (2) & VIF \\
\hline \multirow{2}{*}{ const } & $0.7396^{* *}$ & \multirow{2}{*}{-} & $0.7413^{* *}$ & \multirow{2}{*}{-} \\
\hline & $(0.01642)$ & & $(0.01647)$ & \\
\hline \multirow{2}{*}{ Ln(DENSITY) } & $0.02007^{* *}$ & \multirow{2}{*}{4.385} & $0.02168^{* *}$ & \multirow{2}{*}{4.506} \\
\hline & (0.001849) & & (0.001943) & \\
\hline \multirow{2}{*}{$\operatorname{Ln}(M P)$} & 0.001771 & \multirow{2}{*}{2.972} & 0.001792 & \multirow{2}{*}{2.972} \\
\hline & $(0.001257)$ & & (0.001239) & \\
\hline \multirow{2}{*}{ CP } & $0.0006882^{* *}$ & \multirow{2}{*}{1.247} & $0.0006847^{* *}$ & \multirow{2}{*}{1.247} \\
\hline & $(7.060 \mathrm{e}-05)$ & & $(6.752 e-05)$ & \\
\hline \multirow{2}{*}{ AMW } & $4.036 \mathrm{e}-05^{* *}$ & \multirow{2}{*}{1.918} & $3.373 e-05^{* *}$ & \multirow{2}{*}{1.942} \\
\hline & $(1.014 \mathrm{e}-05)$ & & $(1.023 e-05)$ & \\
\hline \multirow{2}{*}{ UNEMP } & $-0.004238^{* *}$ & \multirow{2}{*}{1.976} & $-0.004378^{* *}$ & \multirow{2}{*}{2.005} \\
\hline & $(0.0002369)$ & & $(0.0002422)$ & \\
\hline \multirow{2}{*}{ BUILT } & $-0.1005^{* *}$ & \multirow{2}{*}{2.34} & $-0.1264^{* *}$ & \multirow{2}{*}{2.412} \\
\hline & $(0.02181)$ & & $(0.02347)$ & \\
\hline \multirow{2}{*}{ HF } & $0.002555^{* *}$ & \multirow{2}{*}{1.333} & $0.002446^{* *}$ & \multirow{2}{*}{1.334} \\
\hline & $(0.0005034)$ & & $(0.0005472)$ & \\
\hline \multirow{2}{*}{ PREPR } & $-0.006870^{* *}$ & \multirow{2}{*}{2.087} & $-0.006907^{* *}$ & \multirow{2}{*}{2.089} \\
\hline & $(0.0003029)$ & & $(0.0003028)$ & \\
\hline \multirow{2}{*}{ POSTPR } & $-0.001375^{* *}$ & \multirow{2}{*}{2.279} & $-0.001629^{* *}$ & \multirow{2}{*}{2.350} \\
\hline & $(0.0003586)$ & & $(0.0003555)$ & \\
\hline \multirow{2}{*}{ MORG } & -0.0004368 & \multirow{2}{*}{1.087} & -0.001259 & 1102 \\
\hline & $(0.0009933)$ & & $(0.0009046)$ & 1.120 \\
\hline ВССTC & $1.028 \mathrm{e}-06^{* *}$ & 1065 & $8.690 \mathrm{e}-07^{*}$ & 1060 \\
\hline 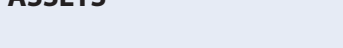 & $(5.055 e-07)$ & 1.000 & $(5.048 e-07)$ & 1.008 \\
\hline va & & & $0.0008034^{* *}$ & 1230 \\
\hline VA & - & - & $(0.0002624)$ & 1.239 \\
\hline Adj. $R^{2}$ & 0.5745 & & 0.5788 & 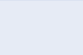 \\
\hline $\mathbf{F}$ & $233.33^{* *}$ & - & $218.08^{* *}$ & - \\
\hline
\end{tabular}

Source: own processing

Robust standard errors in brackets. ${ }^{*}$ significant at 10\%, ${ }^{* *}$ significant at 5\%, N = 2861

explanatory variability of dependent variable. The model remains significant. By adding this variable, we observe that significance level of the variable Net assets per inhabitant has decreased. This could indicate that after taking the activities of voluntary organisations into account, net assets of the municipality are not so important. Coefficients of other control variables remain statistically significant at the same level. The hypothesized relationship between voluntary associations and dependent variable is confirmed - it is positive and statistically significant. Regression results offer evidence that social capital, in the form of voluntary associations' activity at municipal level, is positively related to human development, meaning that municipalities with a higher number of voluntary associations enjoy higher level of human development. This was also observed by Christoforou (2010), who investigated this relationship at the level of European countries. The functioning of various associations can therefore stimulate creation and reinforcement of networks that link individuals of a given community. These networks subsequently help generate trust to other members of the community and its institutions. It also guides actors to abide norms and facilitates reciprocal behaviour. This subsequently leads to improved cooperation, coordination and participation of regional and rural development actors (Putnam, 1993). Kubišová (2016) regards associations linking diverse individuals (in terms of age, education or social status) as the most beneficial for the process of integration. As an example, she mentions sport clubs (with the exception of clubs with homogenous member base), folklore ensembles, tourist associations, and local development associations. 
Since the research shows that membership in associations is positively tied to the level of human development in the given municipality and we explain this by the concept of social capital, it is implied that municipal officials need to utilize social capital in the development of the municipality as any other type of capital. In the past, life in Slovak rural communities has been characterized by a high degree of reciprocity, mutually recognized values and norms. Presently, we can see that this may no longer be the case, limiting the potential of their development (Gajdoš and Pašiak, 2008). In economic development, municipalities utilize social capital inadequately (Kubišová, 2016) and also inhabitants themselves do not realize that, by their activities, they can contribute to the development of their municipalities or regions. It is necessary for any municipality to support inhabitants in setting up voluntary associations and also to act as a co-founder. For municipalities, local associations are also interesting because of the possibility of gaining resources as local organizations can be involved in wider social networks across sectors, enabling them to promote their agenda.

Even though positive and statistically significant relationship between modified human development index and number of voluntary associations per 1,000 inhabitants has been confirmed, the presented model possesses several limitations. Since cross-sectional data is used, its ability to explain causal relationships is limited. In order to reveal true causal relationships between variables, it is necessary to perform regression analysis on panel data. The second limitation is the inability to determine the direction of causal relations. Even though there is a positive relationship between explored variables, there is a possibility that causality is reversed - high level of human development may influence the level of social capital in a municipality. Another limitation is the examined independent variable itself. Individual voluntary associations vary significantly. They are characterized by diverse fields of interests, number of their active members, and scope of their activities. Data specifying number of their members or actual activities performed by those members is not available. Therefore, by using the data available to us, we are not able to determine the actual activities of the voluntary associations.

\section{Conclusion}

Several studies dealing with social capital have shown that increased trust among community members and its institutions and reciprocal relationships play an important role in local development. Our analysis explored the relationship between third sector institutions at the local level and human development of Slovak municipalities. In order to reveal this relationship, we have employed regression analysis. Modified human development index has been constructed to serve as a dependent variable and we have used the number of voluntary associations per 1,000 inhabitants as an independent variable. In order to filter out influence caused by other factors, other variables have been included in the analysis, for example number of organisations owned by municipality or net assets per inhabitants. The results of the analysis have confirmed our hypothesis. The regression model has revealed the existence of positive statistically significant relationship between activities performed by local institutions represented by their number per 1,000 inhabitants and a constructed index of human development. The existence of voluntary associations contributes to the creation of dense network linking actors of local and regional development. Cooperation of these actors is subsequently more efficient and they have access to other forms of capital. As a result, whole communities benefits from their activities. Regarding organisations owned by municipalities, these have proved not significant in the model. On the other hand, there is the statistically significant positive effect of net assets per inhabitant; however, its effects have proved as less significant after the inclusion of voluntary association into the model. The amount of net assets per inhabitant may indicate the level of civic amenities in the given municipality, therefore in the context of social capital it may represent a space where inhabitants and members of associations can meet and strengthen community cohesion. Due to the limitations of cross-sectional data, panel data has to be analysed in the future to allow for the detection of causal relationship between variables.

\section{Acknowledgements}

The paper has been elaborated as an output of the project VEGA1/0789/18.

\section{References}

BINEK, J. et al. 2007. Venkovský prostor a jeho oživení. Brno : Georgetown, 2007. ISBN 80-251-19-5.

BINEK, J. et al. 2009. Synergie ve venkovském prostoru: Aktérii a nástroje rozvoje venkova. Brno : GaREP Publishing, 2009. ISBN 978-80-904308-0-8.

CLINGERMAYER, J. C. - FEIOCK, R. C. 2001. Institutional Constraints and Policy Choice: An Exploration of Local Governance. Albany : State University of New York Press, 2001. ISBN 0-7914-4914-9.

COFFE, H. - GEYS, B. 2005. Institutional performance and social capital: An application to the local government level. In Journal of Urban Affairs [online], vol. 27, 2005, no. 5, pp. 485-501 [Retrieved 2018-03-24]. Retrieved from: https://doi. org/10.1111/j.0735-2166.2005.00249.x

DAVIS, K. E. 2010. Institutions and Economic Performance: An Introduction to the Literature. In DAVIS, K. E. Institutions and Economic Performance [online]. Cheltenham, UK : Edward Elgar, 2010, pp. 1-27 [Retrieved 2018-04-09]. Retrieved from: https:// papers.ssrn.com/sol3/papers.cfm?abstract_id=1520515

EVERS, A. - LAVILLE, J. 2004. The Third Sector in Europe. Cheltenham, UK : Edward Elgar Publishing Limited, 2004. ISBN 1843764008.

FLORA, C. B. et al. 1992. Rural Communities: Legacy and Change. Oxford: Westview Press, 1992. ISBN 0-8133-1477-1.

FUKUYAMA, F. 1995. Trust: the social virtues and the creation of prosperity. New York : Free Press, 1995. ISBN 0684825252

HAIR, J. F. et al. 2014. Multivariate Data Analysis. $7^{\text {th }}$ ed., London : Pearson, 2014. ISBN 0138132631

GAJDOŠ, P. - PAŠIAK, J. 2008. Sociálne zdroje lokálneho a regionálneho rozvoja. Bratislava : VEDA, 2008. ISBN 9788085544534.

HIGH, C. et al. 2005. Understanding informal institutions: Networks and communities in rural development. In Transition in Agriculture, Agricultural Economics in Transition II [online]. Budapest : Hungarian Academy of Sciences, 2005, pp. 1-20 [Retrieved 201803-22]. Retrieved from: http://oro.open.ac.uk/2683/ 
HUMLEROVÁ, V. 2013. Strategie regionálního rozvoje a rozvoje venkova podporované EU a jejich uplatnení v ČR. České Budějovice : JU, 2013.

CHRISTOFOROU, A. 2010. Social capital and human development: an empirical investigation across European countries. In Journal of Institutional Economics [online], vol. 6, 2010, no. 2, pp. 191-214 [Retrieved 2018-03-23]. Retrieved from: 10.1017/ S1744137409990324

JËKABSONE, I - SLOKA, B. 2016. Objective Evaluation of the Wellbeing of the Municipalities in Latvia. In Social Research [online], vol. 34, 2016, no. 1, pp. 42-52 [Retrieved 2018-03-22]. Retrieved from: http://www.su.lt/bylos/mokslo_leidiniai/soc_tyrimai/2014_34/ jekobsone_sloka.pdf

KADEŘÁBKOVÁ, J. - TRHLÍNOVÁ, Z. 2006. Participace občanů na ochraně a využívání kulturního dědictví na českém venkově. In Sborník příspěvků z mezinárodní konference "Venkov je náš svět/ Countryside - our world“. Český Krumlov : ČZU, 2006, pp. 369- 377. ISBN 80-213-1539-3

KUBIŠOVÁ, L. 2016. Úloha sociálneho kapitálu v miestnom rozvoji. Banská Bystrica : Univerzita Mateja Bela, 2016.

MARTIN, R. - SUNLEY, P. 2003. Deconstructing clusters: chaotic concept or policy panacea? In Journal of Economic Geography [online], vol. 3, 2003, no. 1, pp. 5-35 [Retrieved 2018-03-27]. Retrieved from: https://doi.org/10.1093/jeg/3.1.5

MELICHOVÁ, K. 2015. Building social capital - does it facilitate development of rural areas? In Forward - Moving frontiers of rural and regional development, proceedings of research conference. Nitra: SPU, 2015, pp. 86-92. ISBN 978-80-552-1256-2.

NORTH, D. C. 1990. Institutions, Institutional Change and Economic Performance (Political Economy of Institutions and Decisions) Cambridge : Cambridge University Press, 1990. ISBN 0521397340.

PUTNAM, R. D. 1993. The Prosperous Community. In The American Prospect [online], vol. 4, 1993, no. 13, pp. 35-42 [Retrieved 2018-02-28]. Retrieved from: http://prospect.org/article/ prosperous-community-social-capital-and-public-life
PUTNAM, R. 2000. Bowling alone: The collapse and revival of American community. New York : Simon \& Schuster, 2000. ISBN 0743203046

RORIGUEZ-POSE, A. - STORPER, M. 2006. Better rules or stronger communities? On the social foundations of institutional change and its economic effects. In Economic Geography [online], vol. 82, 2006, no. 1, pp. 1-25 [Retrieved 2018-03-02]. Retrieved from: https://doi.org/10.1111/j.1944-8287.2006.tb00286.x

RUPASINGHA, A. et al. 2002. Social and institutional factors as determinants of economic growth: Evidence from the United States counties. In Papers in Regional Science [online], vol. 81, 2002, no. 1, pp. 139-155 [Retrieved 2018-03-18]. Retrieved from: https:// link.springer.com/article/10.1007/s101100100091

SVOBODOVÁ, H. et al. 2011. Synergie ve venkovském prostoru. Brno: GaREP, 2011. ISBN 978-80-904308-8-4

UNITED NATIONS DEVELOPMENT PROGRAMME. 2016. Human Development Report 2016 Human Development for Everyone. New York : United Nations Development Programme, 2016. ISBN 978-92-1-126413-5.

UPHOFF, N. - BUCK, L. 2006. Strengthening Rural Local Institutional Capacities for Sustainable Livelihoods and Equitable Development [online]. 76 p. [Retrieved 2017-10-14]. Retrieved from: https:// openknowledge.worldbank.org/handle/10986/8194

WOOLCOCK, M. 2002. Social Capital in Theory and Practice: Where Do We Stand? In ISHAM, J. - KELLY, T. - RAMASWAMY, S. (eds.). Social Capital and Economic Development: Well-being in Developing Countries [online], Cheltenhem, UK : Edward Elgar, 2002, pp. 18-37. ISBN 9781840646993. Retrieved from: $10.4337 / 9781781950388.00011$

WORLD BANK. 2002. Building institutions for markets. New York : Oxford University Press, 2002. ISBN 0195216075 